\title{
PENGELOMPOKAN KABUPATEN/KOTA DI SUMATERA BARAT BERDASARKAN FAKTOR TERKAIT KEJADIAN DEMAM BERDARAH DENGUE DENGAN METODE FUZZY SUBTRACTIVE CLUSTERING
}

\author{
SRI DELIMAWATI, HAZMIRA YOZZA, MAIYASTRI \\ Program Studi S1 Matematika, \\ Fakultas Matematika dan Ilmu Pengetahuan Alam, Universitas Andalas, \\ Kampus UNAND Limau Manis Padang, Indonesia. \\ email : sridelimawati2121@gmail.com, hazmirayozza@sci.unand.ac.id, \\ maiyastri@sci.unand.ac.id
}

Diterima 15 Desember 2020 Direvisi 29 Desember 2020 Dipublikasikan 12 Januari 2021

\begin{abstract}
Abstrak. Demam berdarah dengue(DBD) adalah penyakit infeksi virus akut yang disebabkan oleh virus dengue. Provinsi Sumatera Barat merupakan salah satu provinsi di Indonesia yang memiliki angka penderita DBD cukup tinggi. Penelitian ini bertujuan untuk mengelompokkan kabupaten/kota di Sumatera Barat berdasarkan faktor terkait kejadian DBD yakni kejadian banjir, penampungan air, fasilitas dan tenaga kesehatan dan penduduk miskin. Metode yang digunakan dalam penelitian ini adalah metode fuzzy subtractive clustering(FSC). Berdasarkan pengolahan dengan metode FSC didapat hasil pengklasteran dengan 2 klaster, 4 klaster, 5 klaster, 7 klaster dan 8 klaster. Dari validitas klaster ditemukan jumlah klaster terbaik yaitu 7 klaster. Berdasarkan karakteristik klaster, secara umum klaster 4 merupakan klaster terbaik dibandingkan dengan klaster lainnya. Klaster 3, klaster 5 dan klaster 7 merupakan klaster terendah, sehingga pada klaster tersebut banyak indikator yang harus mendapat penanganan lebih supaya angka penderita DBD dapat berkurang.
\end{abstract}

Kata Kunci: Demam Berdarah Dengue(DBD), Fuzzy Subtractive Clustering(FSC)

\section{Pendahuluan}

Penyakit demam berdarah dengue(DBD) adalah penyakit infeksi virus akut yang disebabkan oleh virus dengue dan terutama menyerang anak-anak dengan ciri-ciri demam tinggi mendadak dengan manifestasi perdarahan dan bertendensi menimbulkan shock dan kematian. Sarana penularan demam berdarah sendiri berasal dari gigitan nyamuk aedes aegypti dan aedes albocpictus [4]. Penyakit DBD merupakan salah satu masalah kesehatan masyarakat yang penting di Indonesia. Provinsi Sumatera Barat merupakan salah satu provinsi di Indonesia yang memiliki angka

*penulis korespondensi 
penderita DBD cukup tinggi. Banyak faktor yang terkait dengan kejadian DBD, seperti pada kondisi lingkungan yaitu lingkungan yang tidak bersih maupun hal-hal lain yang dapat mempengaruhi kejadian kasus DBD. Pada masing-masing daerah, kondisi faktor-faktor tersebut berbeda sehingga banyaknya kejadian DBD di setiap daerah tersebut juga berbeda. Oleh karena itu perlunya penanganan supaya angka penderita penyakit DBD dapat berkurang. Dalam penanganan tersebut hal pertama yang harus dilakukan adalah mengelompokkan kabupaten/kota mana yang menjadi potensi penyakit DBD tertinggi di Provinsi Sumatera Barat. Pengelompokan tersebut dapat dilakukan berdasarkan faktor-faktor yang mempengaruhi DBD.

Berdasarkan latar belakang tersebut, penulis akan mengkaji lebih lanjut dengan mengelompokkan kabupaten/kota di Sumatera Barat untuk studi kasus demam berdarah tahun 2018 dengan metode fuzzy subtractive clustering dan menganalisis jumlah klaster terbaik yang dapat terbentuk berdasarkan indeks validitas klaster.

\section{Landasan Teori}

\subsection{Analisis Klaster}

Analisis klaster(cluster analysis) merupakan suatu teknik statistik multivariat yang bertujuan untuk mengelompokkan objek-objek berdasarkan kesamaan karakteristik yang dimilikinya. Pengelompokan dilakukan berdasarkan pada sifat kemiripan atau sifat ketidakmiripan antar objek. Objek yang berada dalam kelompok yang sama akan lebih mirip dibandingkan dengan objek pada kelompok yang berbeda [2].

\subsection{Himpunan Fuzzy}

Himpunan crisp adalah nilai keanggotaan $x$ dalam suatu himpunan $A$, yang sering ditulis dengan $\mu_{A}(x)$, memiliki dua kemungkinan, yaitu: 1, yang berarti bahwa suatu elemen menjadi anggota dalam suatu himpunan; dan 0, yang berarti bahwa suatu elemen tidak menjadi anggota dalam suatu himpunan[3]. Himpunan fuzzy didasarkan pada gagasan untuk memperluas jangkauan fungsi keanggotaan pada himpunan crisp sedemikian sehingga fungsi tersebut mencakup bilangan real pada interval $[0,1][6]$.

\subsection{Fuzzy Subtractive Clustering}

Fuzzy clustering adalah metode pengklasteran berdasarkan derajat keanggotaan yang mencakup himpunan fuzzy sebagai dasar pembobotan bagi pengklasteran. Salah satu pendekatan dari fuzzy clustering adalah fuzzy subtractive clustering(FSC). Metode ini pertama kali diperkenalkan oleh Stephen L. Chiu pada tahun 1994. Menurut [1], pengklasteran dengan FSC dilakukan pada data yang telah dinormalisasi. Berikut rumus normalisasi data.

$$
X_{i j}^{*}=\frac{X_{i j}-X_{\operatorname{minj}}}{X_{\operatorname{maxj}}-X_{\operatorname{minj}}}, i=1,2, \cdots, n ; j=1,2, \cdots, m
$$




\subsubsection{Pusat Klaster}

Penentuan pusat klaster adalah langkah awal pada metode FSC. Pada pendekatan ini, beberapa data memiliki potensi tinggi untuk dapat dijadikan pusat klaster. Data ini adalah data dengan jumlah tetangga yang paling banyak. Data yang sudah terpilih sebagai pusat klaster ini kemudian akan dikurangi potensi terhadap data yang lain. Kemudian algoritma memilih data lain yang memiliki jumlah data terbanyak untuk dijadikan pusat klaster yang lain. Hal ini akan dilakukan berulangulang hingga semua data dicobakan [3].

Misalkan terdapat $n$ buah data $\left\{\boldsymbol{X}_{\mathbf{1}}, \boldsymbol{X}_{\mathbf{2}}, \cdots, \boldsymbol{X}_{\boldsymbol{n}}\right\}$, dengan $\boldsymbol{X}_{\boldsymbol{i}}=$ $\left(X_{1 i}, \cdots, X_{m i}\right), m$ adalah banyak variabel. Potensi data ke- $k$ dihitung dari

$$
D_{k}=\sum_{i=1}^{n} e^{-\frac{4\left\|\boldsymbol{X}_{\boldsymbol{k}}-\boldsymbol{X}_{\boldsymbol{i}}\right\|^{2}}{r_{a}^{2}}}
$$

dengan $\boldsymbol{X}_{\boldsymbol{k}}$ adalah vektor data ke- $k, \boldsymbol{X}_{\boldsymbol{i}}$ adalah vektor data ke- $i,\left\|\boldsymbol{X}_{\boldsymbol{k}}-\boldsymbol{X}_{\boldsymbol{i}}\right\|$ adalah jarak euclidean antara $\boldsymbol{X}_{\boldsymbol{k}}$ dengan $\boldsymbol{X}_{\boldsymbol{i}}, n$ adalah jumlah data dan $r_{a}$ adalah jari-jari setiap variabel data.

Misalkan $\boldsymbol{X}_{\boldsymbol{c} \mathbf{1}}$ adalah data yang terpilih sebagai pusat klaster pertama, dengan potensi sebesar $D_{c 1}$. Nilai $D_{c 1}$ selanjutnya menjadi potensi klaster pertama. Pada tahap selanjutnya, dihitung kembali potensi data yang lain dengan mengurangkan potensi sebelumnya dengan potensi pusat klaster pertama tersebut melalui persamaan

$$
D_{k}^{\prime}=D_{k}-D_{c 1} * e^{-\frac{4\left\|\boldsymbol{X}_{\boldsymbol{k}}-\boldsymbol{X}_{\boldsymbol{c 1}}\right\|^{2}}{r_{b}^{2}}}
$$

dengan $D_{k}^{\prime}$ adalah nilai potensi baru data ke- $k$ dan $r_{b}$ adalah jari-jari setiap variabel data. Biasanya $r_{b}$ bernilai lebih besar dibandingkan dengan $r_{a}, r_{b}=q * r_{a}$. Nilai $q$ adalah squash factor biasa dinyatakan $q=1.25$. Setelah potensi baru dari semua data diperoleh, data dengan potensi tertinggi dipilih sebagai pusat klaster yang kedua. Selanjutnya didapatkan pusat klaster kedua, nilai potensi tiap-tiap data dikurangi kembali, demikian seterusnya.

Proses penentuan pusat klaster dilakukan secara iteratif. Iterasi tersebut dihentikan berdasarkan dua nilai, yaitu accept ratio dan reject ratio. Accept ratio dan reject ratio keduanya merupakan suatu bilangan pecahan yang bernilai 0 sampai 1 . Accept ratio merupakan batas bawah suatu data yang menjadi calon pusat klaster diterima menjadi pusat klaster, sedangkan reject ratio merupakan batas atas dimana suatu data yang menjadi calon pusat klaster tidak diterima untuk menjadi pusat klaster. Pada suatu iterasi, jika ditemukan suatu data dengan potensi tertinggi (misal dengan pusat klaster $\boldsymbol{X}_{\boldsymbol{k}}$ dengan potensi $D_{k}$ ), maka dilanjutkan dengan mencari ratio potensi data tersebut dengan potensi tertinggi yang diperoleh pada iterasi pertama (misal pusat klaster pertama $\boldsymbol{X}_{\boldsymbol{c 1}}$ dengan potensi data terbesar klaster pertama $D_{c 1}$ ). Hasil bagi antara $D_{k}$ dengan $D_{c 1}$ ini kemudian disebut dengan ratio.

Untuk menentukan pusat klaster terdapat tiga kondisi yang bisa terjadi dalam suatu iterasi yaitu: 
(1) jika ratio > accept ratio, maka data tersebut diterima sebagai pusat klaster baru,

(2) jika reject ratio $<$ ratio $\leq$ accept ratio, maka data tersebut diterima sebagai pusat klaster baru hanya jika data tersebut terletak pada jarak yang cukup jauh dengan pusat klaster yang lainnya,

(3) jika ratio $\leq$ reject ratio, maka sudah tidak ada lagi data yang dipertimbangkan untuk menjadi calon pusat klaster, iterasi dihentikan.

\subsubsection{Derajat Keanggotaan}

Berdasarkan data sampel dapat diduga simpangan baku dari masing-masing variabel menggunakan rumus

$$
\sigma_{j}=\frac{r_{a} *\left(X_{\operatorname{maxj}}-X_{\operatorname{minj}}\right)}{\sqrt{8}}, \quad j=1,2, \cdots, m .
$$

Pusat klaster $(\boldsymbol{C})$ yang dihasilkan dari tahap pertama tadi dan simpangan baku $(\sigma)$ pada persamaan (2.4) digunakan untuk menentukan nilai parameter fungsi keanggotan gauss. Dengan fungsi tersebut, derajat keanggotaan suatu titik data $X_{i}$ pada klaster ke-l $l(l=1,2, \cdots, p)$ adalah $[3]$ :

$$
\mu_{l i}=e^{-\sum_{j=1}^{m} \frac{\left(\boldsymbol{X}_{\boldsymbol{i} \boldsymbol{j}}-\boldsymbol{C}_{\boldsymbol{l} \boldsymbol{j}}\right)^{2}}{2 \sigma_{j}^{2}}} .
$$

\subsubsection{Keanggotaan Klaster}

Dalam menentukan keanggotaan klaster, digunakan nilai derajat keanggotaan yang telah didapatkan sebelumnya. Derajat keanggotaan terbesar menunjukkan bahwa kecenderungan tertinggi suatu data untuk masuk menjadi anggota klaster tersebut[3].

\subsection{Algoritma Fuzzy Subtractive Clustering}

Algoritma fuzzy subtractive clustering adalah sebagai berikut[3].

(1) Menginput data yang akan diklasterkan berupa matriks $\left(\mathbf{X}_{i j}\right)$, dengan $i=$ $1,2, \cdots, n$ dan $j=1,2, \cdots, m$.

(2) Menetapkan nilai jari-jari $\left(r_{a}\right)$, squash factor $(q)$, accept ratio dan reject ratio.

(3) Menentukan nilai minimum $\left(X_{\min }\right)$ dan maksimum $\left(X_{\max }\right)$.

(4) Menormalisasi setiap data menggunakan persamaan (2.1).

(5) Menentukan potensi awal tiap titik data, $D_{k}(k=1,2, \cdots, n)$ dengan persamaan (2.2).

(6) Menentukan nilai $D_{c 1}=D_{k \max }$, khusus untuk iterasi ke-1.

(7) Menghitung nilai Ratio $=\frac{D_{k m a x}}{D_{c 1}}$, untuk iterasi ke-2 dan seterusnya. Setelah nilai ratio diperoleh, ada tiga keadaan yang dapat terjadi:

(a) jika nilai ratio > accept ratio, calon pusat klaster dapat diterima sebagai pusat klaster baru, 
(b) jika nilai ratio < accept ratio dan nilai ratio > reject ratio, calon baru akan diterima jika keberadaannya cukup jauh dari pusat klaster yang telah ada. Misal $\boldsymbol{V}$ adalah calon pusat klaster. Prosedur yang dilakukan adalah:

i. menghitung jarak calon pusat klaster $\boldsymbol{V}$ dengan pusat klaster yang lain $C_{l}$ dengan rumus:

$$
S d_{l}=\sum_{j=1}^{m}\left(\frac{\boldsymbol{V}_{\boldsymbol{j}}-\boldsymbol{C}_{\boldsymbol{l} \boldsymbol{j}}}{r_{j}}\right)^{2}
$$

ii. menentukan jarak terdekat $\boldsymbol{V}$ dengan pusat klaster lain $M d$, hitung

$$
M d s=\sqrt{M d}
$$

A. jika $($ ratio $+M d s) \geq 1$, calon pusat klaster diterima sebagai pusat klaster baru,

B. jika $($ ratio $+M d s)<1$, calon pusat klaster tidak diterima dan tidak akan dipertimbangkan kembali sebagai pusat klaster dan potensi data tersebut diset menjadi 0 ,

(c) jika nilai ratio < accept ratio dan nilai ratio < reject ratio, sudah tidak ada lagi calon pusat klaster baru dan iterasi dihentikan.

(8) Mengurangi potensi titik-titik data yang lain dengan persamaan (2.3).

(9) Menentukan nilai $D_{k \max }^{\prime}$.

(10) Mengulangi langkah 7-9 sampai proses iterasi berhenti.

(11) Mengembalikan pusat klaster dari bentuk ternormalisasi ke bentuk semula.

$$
C_{l j_{\text {denorm }}}=C_{l j} *\left(X_{\text {maxj }}-X_{\text {minj }}\right)+X_{\text {minj }}
$$

(12) Menghitung nilai simpangan baku klaster dengan persamaan (2.4).

(13) Menghitung derajat keanggotaan suatu titik data $X_{i}$ pada klaster ke- $l(l=$ $1,2, \cdots, p)$ dengan persamaan $(2.5)$.

(14) Menentukan keanggotaan klaster.

\subsection{Validitas Klaster}

Salah satu indeks validitas yang hanya melibatkan nilai keanggotaan adalah indeks modified partition coefficient(MPC). MPC merupakan indeks validitas hasil perbaikan dari metode partition coefficient(PC). Nilai MPC didefinisikan dengan persamaan:

$$
M P C=1-\frac{p}{p-1}(1-P C)
$$

Adapun persamaan indeks PC yaitu :

$$
P C=\frac{1}{n} \sum_{l=1}^{p} \sum_{i=1}^{n}\left(\mu_{l i}\right)^{2}
$$

Nilai MPC berkisar antara $0 \leq \mathrm{MPC} \leq 1$. Penentuan hasil klaster optimal dari beberapa jumlah klaster yang dihasilkan ditentukan dari nilai MPC yang terbesar[5]. 


\section{Metode Penelitian}

Data yang digunakan adalah data sekunder mengenai faktor terkait kejadian DBD kabupaten/kota di Sumatera Barat pada tahun 2018 yang bersumber dari Survei Sosial Ekonomi Nasional(Susenas) Badan Pusat Statistik Provinsi Sumatera Barat tahun 2018.

Variabel yang digunakan dalam penelitian ini adalah persentase penduduk miskin $\left(X_{1}\right)$, jumlah penderita penyakit DBD $\left(X_{2}\right)$, jumlah desa/kelurahan yang mengalami banjir $\left(X_{3}\right)$, jumlah puskesmas $\left(X_{4}\right)$, jumlah dokter umum $\left(X_{5}\right)$ dan persentase rumah tangga dengan penampungan air hujan $\left(X_{6}\right)$.

Tahap-tahap yang dilakukan adalah :

(1) mendeskripsikan masing-masing variabel yang digunakan dalam penelitian,

(2) melakukan pengklasteran menggunakan algoritma FSC,

(3) menentukan rekomendasi klaster terbaik dengan menggunakan indeks validitas klaster,

(4) menginterpretasikan hasil pengklasteran.

\section{Pembahasan}

\subsection{Hasil Pengklasteran}

Proses klastering mengggunakan algoritma FSC dengan mengambil $r=$ $0.40,0.50,0.60,0.70,0.80,0.90$. Berdasarkan output menggunakan software SPSS 16, Matlab 2017b maupun perhitungan manual menggunakan Microsoft Excel, banyak klaster yang terbentuk dengan $r=0.40,0.50,0.60,0.70,0.80,0.90$ adalah sebagai berikut.

Tabel 1. Banyaknya Klaster yang Terbentuk dengan $r=0.40,0.50,0.60,0.70,0.80,0.90$

\begin{tabular}{|c|c|}
\hline Jari-jari(r) & Banyaknya Klaster \\
\hline 0.40 & 8 \\
\hline 0.50 & 7 \\
\hline 0.60 & 7 \\
\hline 0.70 & 5 \\
\hline 0.80 & 4 \\
\hline 0.90 & 2 \\
\hline
\end{tabular}

Dari Tabel 1 dapat dilihat bahwa banyaknya klaster yang diperoleh dengan $r=0.40$ adalah 8 klaster, $r=0.50,0.60$ adalah 7 klaster, $r=0.70$ adalah 5 klaster, $r=0.80$ adalah 4 klaster dan $r=0.90$ adalah 2 klaster.

\subsection{Rekomendasi Klaster Terbaik}

Perhitungan nilai indeks modified partition coefficient(MPC) dilakukan pada seluruh jari-jari yang membentuk beberapa jumlah klaster yang telah dianalisis 
menggunakan metode FSC. Berikut adalah nilai indeks MPC untuk $r=$ $0.40,0.50,0.60,0.70,0.80,0.90$.

Tabel 2. Nilai MPC

\begin{tabular}{|c|c|c|}
\hline Jari-jari (r) & Banyaknya Klaster & MPC \\
\hline 0.40 & 8 & 0.467 \\
\hline 0.50 & 7 & 0.462 \\
\hline 0.60 & 7 & 0.558 \\
\hline 0.70 & 5 & 0.393 \\
\hline 0.80 & 4 & 0.367 \\
\hline 0.90 & 2 & 0.382 \\
\hline
\end{tabular}

Berdasarkan Tabel 2 nilai indeks MPC yang terbesar terdapat pada jari-jari $(r)=0.60$. Hal ini menunjukkan klaster tersebut merupakan jumlah klaster yang terbaik yang digunakan dalam permasalahan ini. Jari-jari $(r)=0.60$ diperoleh kesamaan kecenderungan data yang masuk pada setiap klaster, berikut klaster yang terbentuk dengan $r=0.60$.

Tabel 3. Hasil Pengklasteran dengan $r=0.60$

\begin{tabular}{|c|c|}
\hline Klaster & Nama Kabupaten/Kota \\
\hline Klaster 1 & $\begin{array}{r}\text { Kab. Solok Selatan, Kota Solok, Kota Sawahlunto, Kota Padang Panjang, } \\
\text { Kota Bukittinggi, Kota Payakumbuh, Kota Pariaman }\end{array}$ \\
\hline Klaster 2 & $\begin{array}{r}\text { Kab. Sijunjung, Kab. Solok, Kab. Pasaman, } \\
\text { Kab. Dharmasraya, Kab. Pasaman Barat }\end{array}$ \\
\hline Klaster 3 & Kab. Padang Pariaman, Kab. Lima Puluh Kota, \\
\hline Klaster 4 & Kab. Tanah Datar, Kab Agam \\
\hline Klaster 5 & Kabupaten Mentawai \\
\hline Klaster 6 & Kota Padang \\
\hline Klaster 7 & Kab. Pesisir Selatan \\
\hline
\end{tabular}

\subsection{Karakteristik Klaster Terbaik}

Setelah klaster terbentuk, diambil rata-rata dari masing-masing faktor yang terkait dengan DBD terhadap seluruh objek penelitian (19 kabupaten/kota di Sumatera Barat), dimana faktor-faktor tersebut yaitu penduduk miskin, penderita DBD, desa/kelurahan yang megalami banjir, puskesmas, dokter umum dan rumah tangga dengan penampungan air hujan $(\bar{X})$. Selanjutnya untuk masing-masing klaster juga diambil rata-rata pada masing-masing variabel $\left(\bar{X}_{l}\right)$. Pada setiap peubah di dalam klaster diberi tanda, jika $\bar{X}_{l}>\bar{X}$ maka diberi tanda positif $(+)$, sedangkan jika 
$\bar{X}_{l}<\bar{X}$ maka diberi tanda negatif $(-)$. Adapun karakteristik hasil pengklasteran disajikan pada tabel berikut.

Tabel 4. Karakteristik Hasil Pengklasteran

\begin{tabular}{|c|c|c|c|c|c|c|}
\hline Klaster & $X_{1}$ & $X_{2}$ & $X_{3}$ & $X_{4}$ & $X_{5}$ & $X_{6}$ \\
\hline Klaster 1 & - & - & - & - & - & - \\
\hline Klaster 2 & + & - & + & + & + & - \\
\hline Klaster 3 & + & - & + & + & - & + \\
\hline Klaster 4 & - & + & - & + & + & - \\
\hline Klaster 5 & + & - & - & - & - & + \\
\hline Klaster 6 & - & + & + & + & + & - \\
\hline Klaster 7 & + & + & + & + & - & - \\
\hline
\end{tabular}

Pada penelitian ini variabel persentase penduduk miskin $\left(X_{1}\right)$, jumlah penderita DBD $\left(X_{2}\right)$, jumlah desa/kelurahan yang mengalami banjir $\left(X_{3}\right)$ dan persentase rumah tangga dengan penampungan air hujan $\left(X_{6}\right)$ jika bertanda $(-)$ maka kemungkinan terjadinya DBD sedikit pada suatu klaster tersebut. Untuk jumlah puskesmas $\left(X_{4}\right)$ dan jumlah dokter umum $\left(X_{5}\right)$ jika bertanda $(+)$ maka kemungkinan terjadinya DBD sedikit pada suatu klaster tersebut.

Berdasarkan Tabel 4 dapat dilihat bahwa klaster 1, klaster 2 dan klaster 6 dapat dikatakan tingkat penanganannya baik. Klaster 4 dapat dikatakan tingkat penanganannya sangat baik. Klaster 3 , klaster 5 anganannya kurang baik.

\section{Kesimpulan}

Berdasarkan hasil penelitian ini, dapat diambil kesimpulan bahwa pengelompokan berdasarkan faktor terkait kejadian DBD dengan menggunakan metode FSC dimana jumlah klaster terbaiknya adalah 7 klaster dengan jari-jari $(r)=0.60$. Berdasarkan karakteristik klaster, secara umum klaster 4 dapat dikatakan klaster terbaik. Klaster 3 , klaster 5 dan klaster 7 adalah klaster terendah, sehingga harus mendapat penanganan lebih supaya angka penderita penyakit DBD dapat berkurang.

\section{Ucapan Terima kasih}

Penulis mengucapkan terimakasih kepada Ibu Izzati Rahmi, H.G., M.Si, Ibu Dr. Arrival Rince Putri dan Ibu Monika Rianti Helmi M.Si yang telah memberikan masukan dan saran sehingga paper ini dapat diselesaikan dengan baik.

\section{Daftar Pustaka}

[1] Chiu, S.L. 1994. Fuzzy Model Identification Based on Cluster Estimation. Journal of Intelligent and Fuzzy Systems. Rockwell Science Center. California.

[2] Johnson R, Wichern D. 2007. Applied Multivariate Statistical Analysis, Sixth Edition. New Jersey : Pearson Education.

[3] Kusumadewi dan Purnomo. 2004. Aplikasi Logika Fuzzy untuk Pendukung Keputusan. Edisi 2. Graha Ilmu. Yogyakarta. 
158 Sri Delimawati $d k k$.

[4] Siregar, Faziah A. 2004. Epidemiologi dan Pemberantasan Demam Berdarah Dengue(DBD) di Indonesia. Fakultas Kesehatan Masyarakat. Universitas Sumatra Utara. http://repository.usu.ac.id/bitstream/1 23456789/3673/3/fkmfazidah3.pdf.txt

[5] Xie, N., L.Hu, N.Luktarhan, dan K.Zhao. 2011. A Classification of Cluster Validity Indexes Based on Membership Degree and Aplication. Web Information System and Mining. $43-50$.

[6] Yan, J., M. Ryan and J. Power. (1994). Using Fuzzy Logic Towards Intelligent Systems. Prentice Hall International, London. 